\title{
ANALYSIS OF SCIENTIFIC MODELS TO THE PROBLEM OF APPLICATIONS THROUGH EPISTEMOLOGICAL PRINCIPLES IN PSYCHOLOGY
}

Babajanyan I.H. (YSU, Yerevan, Armenia) i.babajanyan95@gmail.com

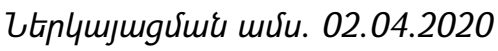

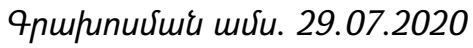

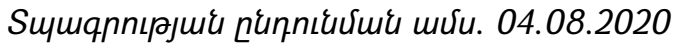

The article will identify the key points of the epistemological principles in psychology as well as will educate about the approaches and their usefulness well as some background information related to the models that have been previously studied in the field of Psychology. The models aim to focus on the knowledge and the comparison between justified belief and opinion. Moreover, they also try to educate the aspects of cognitive processing's which may include the argumentative processes, how one perceives the world experiences through epistemological assumptions.

Current trends in psychological research are explained in the article through epistemological principles. In addition to the descriptions of each psychological study, which used epistemological methods to study the thought processes of various populated samples, a comparative analysis is also provided.

Keywords: epistemology, principles, cognition, knowledge, justification, development.

Epistemology is defined in multiple ways in science. However, the word is originally from Greek and means knowledge. It is the study of the nature of knowledge, justification and the rationality of belief. Epistemology addresses many issues in science and in the psychological research such as what makes the belief true? Or how do we know that we know it scientifically? These are just some examples of the most popular questions that epistemology addresses in the world of philosophy. According to the philosophers, there are quite big distinction between Knowing that and Knowing how. It is very important to understand and at the same time be able to identify and/or recognize as well as distinguish justified belief from fact and/or opinion.

The purpose of our theoretical research was to analyze the key provisions of epistemological principles that are most acceptable in modern psychology, which will determine the degree of their usefulness, which will allow us to focus on knowledge and comparison of reasonable beliefs and opinions for choosing a research methodology. 
As mentioned above, epistemological branches that need to be present in order to be identified such as belief, truth, and justification. In which, the belief is basically the truth that we believe in or things that we accept as true. Whereas, the truth is explained as something that is scientifically known and evidenced by scientists who had worked on the issue. If the truth is known than it cannot be false which means that something might be known or true scientifically but in the practical world, it may or may not be as true as it seems. On the other hand, justification is the explanation of how much we believe in solutions and how much those beliefs will motivate or make us optimistic towards the goal [2].

The other difference that exists between psychology and epistemology is the idea of which one of these concepts are more concerned with why men hold the beliefs that they do. There are some famous psychologists who have contributed their studies and theories through epistemology. One of the famous and popular theory that Jean Piaget introduced in 1950. His work of "Genetic Epistemology" used the concept of epistemology in many ways such as intellectual development and initiating the interest of developmental psychologists in this intersection of philosophy and psychology [6].

There are three main domains of the epistemological research which cut across the six general issues. According to Hofer and Pintrich's article that has been published in 1997.

"One group has been largely interested in how individuals interpret their educational experience, second group of researchers have been interested in how epistemological assumptions influence thinking and reasoning processes focusing on reflective judgment," "The third and most recent line of work has taken the approach that epistemological ideas are a system of beliefs that may be more or less independent rather, than reflecting a coherent developmental structure." These domains also had created central theories and models of epistemological development and epistemological beliefs. Some of the most useful and popular models are: [3], [4].

\section{Perry's Scheme of Intellectual and Ethical Development \\ Women's way of knowing \\ Epistemological Reflection Model \\ Reflective judgement Model \\ Argumentative Reasoning \\ Epistemological beliefs}

These models would help oneself to identify their way of understanding how they think what knowledge is and how one knows numerous theoretical and methodological issues. The methods will be broken down in the following paragraphs. 
Table 1. The main epistemological models.

\begin{tabular}{|c|c|c|c|c|}
\hline $\begin{array}{l}\text { Intellectual } \\
\text { and Ethical } \\
\text { Development } \\
\text { (Perry) }\end{array}$ & $\begin{array}{l}\text { Women's } \\
\text { Way of } \\
\text { Knowing } \\
\text { (Belenky et } \\
\text { al.) }\end{array}$ & $\begin{array}{l}\text { Epistemologic } \\
\text { al Reflection } \\
\text { (Baxter } \\
\text { Magolda) }\end{array}$ & $\begin{array}{l}\text { Reflective } \\
\text { Judegment } \\
\text { (King and } \\
\text { Kitchener) }\end{array}$ & $\begin{array}{l}\text { Argumentative } \\
\text { Reasoning } \\
\text { (Kohn) }\end{array}$ \\
\hline Dualism & $\begin{array}{l}\text { Silence } \\
\text { Received } \\
\text { Knowledge }\end{array}$ & $\begin{array}{l}\text { Absolute } \\
\text { knowing }\end{array}$ & $\begin{array}{l}\text { Pro- } \\
\text { Reflective } \\
\text { Thinking }\end{array}$ & Absolutists \\
\hline Multiplicity & $\begin{array}{l}\text { Subjective } \\
\text { Knowledge }\end{array}$ & $\begin{array}{l}\text { Transitional } \\
\text { Knowing }\end{array}$ & $\begin{array}{l}\text { Quasi- } \\
\text { Reflective } \\
\text { Thinking }\end{array}$ & Multiplists \\
\hline Relativism & $\begin{array}{l}\text { Procedural } \\
\text { Knowledge }\end{array}$ & $\begin{array}{l}\text { Independent } \\
\text { Knowing }\end{array}$ & $\begin{array}{l}\text { Reflective } \\
\text { Thinking }\end{array}$ & Evaluatists \\
\hline $\begin{array}{l}\text { Commitment } \\
\text { within } \\
\text { Relativism }\end{array}$ & $\begin{array}{l}\text { Constructed } \\
\text { Knowledge }\end{array}$ & $\begin{array}{l}\text { Contextual } \\
\text { Knowing }\end{array}$ & & \\
\hline
\end{tabular}

Note: the above indicated chart has been adapted by using The Development of Epistemological Theories: Beliefs About Knowledge and Knowing and Their Relation to Learning: by Hofer B. and Pintrich P. [4].

Perry was the first researcher that suggested the idea of how students can lead to the meaning of their experiences by using epistemological beliefs in his longitudinal study. The study took almost 15 years to come up with a conclusion. The study has two parts which means there have been two studies done by Perry in order to investigate the results. The first tool that Perry created for his study was the CLEV, which stands for Check list of Educational Values [4], [7].

Perry conducted his research by using various tasks, assessment, tools, and techniques but all of these had something in common to assess the individuals. Initially, Perry wanted to encourage the individuals/college students to open up more to the authorities as to help them to understand the way that they perceive the world's experiences and how they deal with the new and unknown experiences. Moreover, they created a scheme of intellectual and ethical development that included a sequence of nine positions [4], [7].

The second longitudinal study came out right after the first one in order to validate the previously found schemes but at this time, they have eliminated 22 women from the sample and kept only two for unknown reasons [4], [7].

Perry mentioned in his study that change is happening because of the lack of stability or equilibrium. According to Perry (1970), individuals respond to new experiences by either using the previously predisposition cognitive frameworks and 
trying to adjust to the original framework by itself. Later in the study, Perry gets the nine sequences clustered into four sequential categories that are Dualism, multiplicity, relativism, commitment within relativism.

Although Perry had many limitations in his study, however, he was able to come up with a conclusion that the meaning the students make is not solely based on the personality traits but they based on developmental processes.

After Perry had published his theory, there were many critiques appeared in terms of the sample that Perry had used. Kohlberg created the theory of moral development in 1960 mentioned that Perry's theory focused more on males and there might be discrepancies between the gender and also indicated that most of the psychological theories are obtained from male experiences and that females also need to be included in the sample in order to receive effective results [7].

Anyway, Belenky et al in 1986, had decided to conduct their own study where they would focus on only females because they thought that females need to be heard and evaluated in terms of perceiving the outside experiences. She thought that majority of males will be judged deficiently because of the lack of the enough specific qualities or perspectives. Her study focused on only females but she did not choose only college students for her sample but instead, she chose women who were also involved in human service agencies. She indicated that the conducted study will not be gender specific but most likely will be gender related in regards to emphasizing on nature of the learning [4], [9].

The study consisted of variety of questionnaires for the females to respond. The interviews lasted from two hours to five hours to deeply understand their own point of views. They did in-dept interviews to investigate their nature of learning new life experiences where their opinions are mattered and constructed only by them without anyone interfering the experimental process [4], [9].

Belenky's findings were not that different than Perry's. She concluded that there might be some differences between genders but the thinking patterns were most likely similar in some ways. Belenky's models are Silence received knowledge, subjective knowledge, procedural knowledge, and constructed knowledge [4], [9].

Baxter Magolda was the next researcher that went ahead and conducted the next study on the epistemological development and how epistemological assumptions make a difference on the interpretations of educational experiences in 1970. Baxter attempted to express student's thought process in order to identify the gaps between the other two theories by analyzing Perry and Belenky's theories. He initially wanted to focus on the outliers of the previously done studies that did not fit into the traditional pattern models. After carefully reviewing the theories, Baxter made a sample of 101 students from one institution consists of females and males as well as graduate and undergraduate students from diverse populations. However, he also 
included three individuals from minority population. The study was selected to be a longitudinal study, which would take 5 years to gather data [1], [4].

Baxter created a questionnaire called MER, which stands for Measure of Epistemological Reflection. He would provide the questionnaires to the students to complete and then return the completed versions. His interviews were based on a yearly basis and each year had different protocols to follow [1], [4].

The results were not very different from the other studies but he did conclude to see some discrepancies in gender related patterns. However, he was able to come up with his own models and was able to explain his theory more in-dept by suggesting his models. The models are as follows: Absolute knowing, transitional knowing, independent knowing, and contextual knowing.

King and Kitchener were the next generational researchers that wanted to get more in-dept information on understanding the epistemic assumptions that may focus on the basis of reasoning cognitively, in other words, they wanted to conduct a study where they would find out the process of impurities of reflective judgement.

Furthermore, the study took 15 years. They chose high-school students to middle age adults to see how they think through difficult situations where they had to made a reasonable and the best decision that they think would fit the best in that particular situation. The study consisted of an interview where they would be asking to think through four difficult problems and then they got asked to respond to six follow up questions for the further assessment. The study was pilot tested and had three round processes. They created seven stage developmental model that was supposed to focus on the way the individuals perceive the outside world of what is known and what is unknown as well as corresponding ways of reasoning to the hostile problems and beliefs [2], [4].

The study got published in 1994 and the findings were very interesting. They found out that the individuals who had higher education were most likely to respond effectively to the problems than others. They came up with different models to explain their study such as pro-reflective thinking, quasi-reflective thinking, and reflective thinking. In other words, the education related to the reflective judgement [2], [4].

The next theory is published by Kuhn in 1991. Her initial study aimed to investigate the argumentative reasoning and the epistemological perspectives. She gave the participants current urban social problems and explored how they would respond to each situation. The participants age range was from teens, 20s, 40s, and 60 s. She interviewed them twice and interviews lasted approximately 45 minutes to 90 minutes. She later came up with three epistemological views which indicated that higher education might be linked to higher epistemological level. Finally, the levels are absolutists, multiplists, and evaluatist [4], [5].

Lastly, Schommer also conducted a study on this topic in 1990 to evaluate the comprehension and academic performance. She created a questionnaire, which 
consisted 63 short statement epistemological belief questions and assessed by using the Likert scale from one to five. The 63 item questions meant to measure the source of knowledge, certainty of knowledge, organization of knowledge, control of learning, and speed of learning. The study was conducted by pilot method and used factor analysis to interpret the results. Although Schommer indicated that learners can be proceeding some aspects of their lives from a great deal of knowledge, it does not necessarily mean that they can do it in all life situations, there are still many aspects of the research that remained unresolved and needs further data to support it [4], [8].

In conclusion, some the theories overlap with the same information by keep referring to Piaget's theory of "Genetic Epistemology," which focused on the cognitive thinking through the developmental stages. In contrast, the Reflective Judgment model used some aspects from Developmental psychology but it mostly focused more on the educational level of the participants [4], [6].

Thus, a theoretical analysis of the key provisions of epistemological principles in psychology revealed the main approaches and models that have gained popularity in many studies. and their usefulness, as well as some background information on models previously studied in the field of psychology. Consideration of the epistemological principles unites attempts to establish and justify, the universal right to form and applied to a specific psychological research that is conducive to develop a methodology for the theoretical, empirical and practical activity of the psychologist [9].

\section{References.}

1. Baxter Magolda, M. B. (2004). Evolution of a constructivist conceptualization of epistemological reflection. Educational Psychologist, 39 (1), pp. 31-42.

2. Bendixen, L.D., Dunkle, M.E., \& Schraw, G. (1994). Epistemological beliefs and reflective judgement. Psychological Reports, 75 (3_suppl), 1595-1600.

3. Changwoo Jeong, Hyemin Han, Improving Epistemological Beliefs and Moral Judgment Through an STS-Based Science Ethics Education Program// Science and Engineering Ethics, 2014, 20(1):197-220/ DOI:10.1007/s11948-013-9429-4.

4. Hofer, B. K., \& Pintrich, P. R. (1997). The development of epistemological theories: Beliefs about knowledge and knowing and their relation to learning. Review of educational research, 67(1), pp. 88-140.

5. Keefer, M.W. (1996). Distinguishing practical and theoretical reasoning: A critique of Deanna Kuhn's theory of informal argument. Informal Logic, 18(1).

6. Kitchener, R.F. (1986). Piaget's theory of knowledge: Genetic epistemology \& scientific reason. Yale University Press.

7. Kloss, R.J. (1994). A nudge is best: Helping students through the Perry scheme of intellectual development. College Teaching, 42(4), pp.151-158. 
8. Schommer, M. (1990). Effects of beliefs about the nature of knowledge on comprehension. Journal of educational psychology, 82(3), 498p.

9. Wickramasinghe, M. (2006, November). An epistemology of gender. An aspect of being as a way of knowing. In Women's Studies International Forum, Vol. 29, No. 6, pp. 606-611.

\section{АНАЛИЗ НАУЧНЫХ МОДЕЛЕЙ К ПРОБЛЕМЕ ПРИМЕНЕНИЯ ЭПИСТЕМОЛОГИЧЕСКИХ ПРИНЦИПОВ В ПСИХОЛОГИИ}

Бабаджанян И. О. (ЕГУ, Ереван, Армения)

В статье определены ключевые пункты эпистемологических принципов в психологии, представлены подходы и их эффективность, а также базовая информация, относящаяся к моделям, которые ранее были изучены в психологии. Модели нацелены на то, чтобы сосредоточить внимание на сравнении обоснованных убеждений и мнений. С помощью этих моделей можно разъяснить аспекты когнитивной обработки, которые могут включать в себя процессы аргументации, т.е. то, как человек воспринимает мир через эпистемологические допущения.

В статье современные тенденции в психологических исследованиях объясняются с помощью эпистемологических принципов. В дополнение к описанию каждого психологического исследования, в котором использовались эпистемологические методы для изучения мыслительных процессов различных популяционных выборок, также предоставляется сравнительный анализ.

Ключевые слова: эпистемология, принципы, познание, знание, обоснование, развитиe.

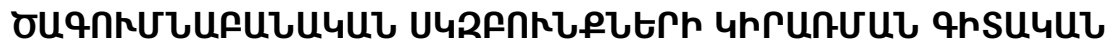

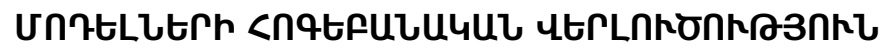

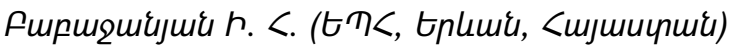

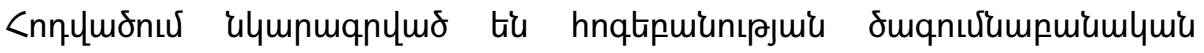

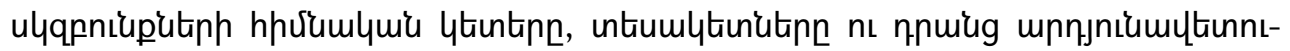

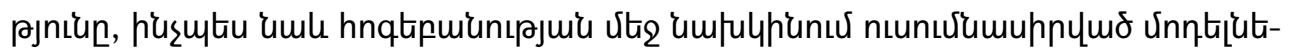

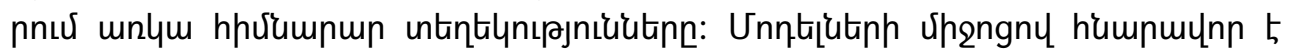

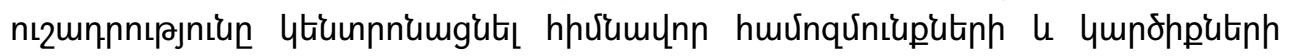

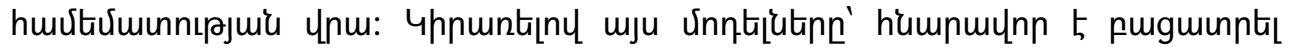

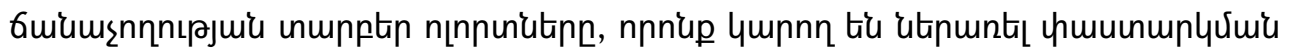

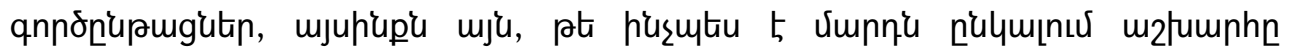

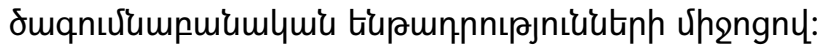




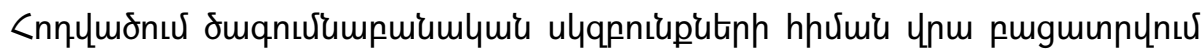

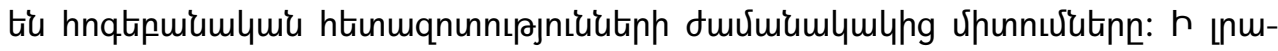

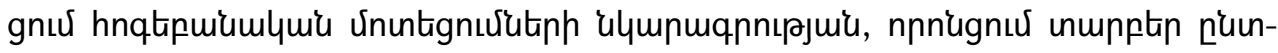

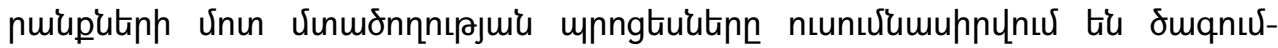

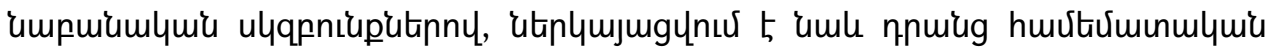

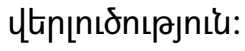

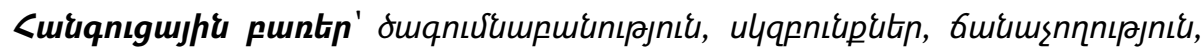

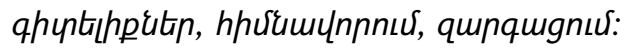

